Nevada

Environmental

Restoration

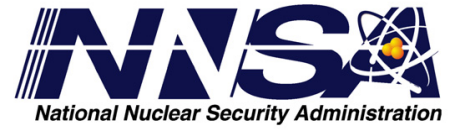

Project

\title{
Addendum to the Closure Report for Corrective Action Unit 398: Area 25 Spill Sites, Nevada Test Site, Nevada
}

Controlled Copy No::

Revision No.: 0

October 2008

Approved for public release; further dissemination unlimited.

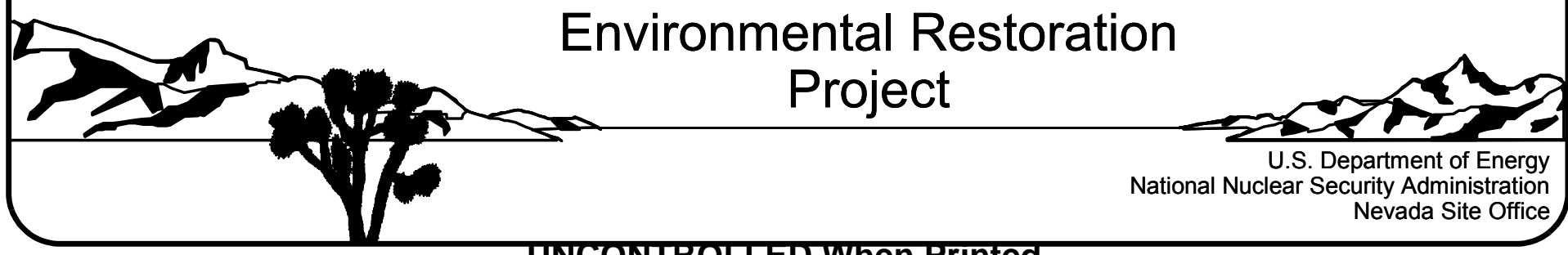


Available for public sale, in paper, from:

U.S. Department of Commerce

National Technical Information Service

5285 Port Royal Road

Springfield, VA 22161

Phone: 800.553 .6847

Fax: 703.605.6900

Email: orders@ntis.gov

Online ordering: http://www.ntis.gov/ordering.htm

Available electronically at $\underline{h t p: / / w w w . o s t i . g o v / b r i d g e ~}$

Available for a processing fee to U.S. Department of Energy and its contractors, in paper, from:

U.S. Department of Energy

Office of Scientific and Technical Information

P.O. Box 62

Oak Ridge, TN 37831-0062

Phone: 865.576 .8401

Fax: 865.576.5728

Email: reports@adonis.osti.gov

Reference herein to any specific commercial product, process, or service by trade name, trademark, manufacturer, or otherwise, does not necessarily constitute or imply its endorsement, recommendation, or favoring by the United States Government or any agency thereof or its contractors or subcontractors. 


\title{
ADDENDUM TO THE CLOSURE REPORT FOR CORRECTIVE ACTION UNIT 398: AREA 25 SPILL SITES, NEVADA TEST SITE, NEVADA
}

\author{
U.S. Department of Energy \\ National Nuclear Security Administration \\ Nevada Site Office \\ Las Vegas, Nevada
}

Controlled Copy No.:

Revision No.: 0

October 2008

Approved for public release; further dissemination unlimited. 


\section{Addendum to the Closure Report for Removal of the Use Restriction}

This document constitutes an addendum to the April 2003, Closure Report for Corrective Action Unit 398: Area 25 Spill Sites as described in the document Recommendations and Justifications for Modifications for Use Restrictions Established under the U.S. Department of Energy, National Nuclear Security Administration Nevada Site Office Federal Facility Agreement and Consent Order (UR Modification document) dated February 2008. The UR Modification document was approved by NDEP on February 26, 2008. The approval of the UR Modification document constituted approval of each of the recommended UR modifications. In conformance with the UR Modification document, this addendum consists of:

- This cover page that refers the reader to the UR Modification document for additional information

- The cover and signature pages of the UR Modification document

- The NDEP approval letter

- The corresponding section of the UR Modification document

This addendum provides the documentation justifying the cancellation of the UR for CAS 25-25-17, Subsurface Hydraulic Oil Spill. This UR was established as part of a Federal Facility Agreement and Consent Order (FFACO) corrective action and is based on the presence of contaminants at concentrations greater than the action levels established at the time of the initial investigation (FFACO, 1996; as amended August 2006).

Since this UR was established, practices and procedures relating to the implementation of risk-based corrective actions (RBCA) have changed. Therefore, this UR was re-evaluated against the current RBCA criteria as defined in the Industrial Sites Project Establishment of Final Action Levels (NNSA/NSO, 2006c). This re-evaluation consisted of comparing the original data (used to define the need for the UR) to risk-based final action levels (FALs) developed using the current Industrial Sites RBCA process.

The re-evaluation resulted in a recommendation to remove the UR because contamination is not present at the site above the risk-based FALs. Requirements for inspecting and maintaining this UR will be canceled, and the postings and signage at this site will be removed. Fencing and posting may be present at this site that are unrelated to the FFACO UR such as for radiological control purposes as required by the NV/YMP Radiological Control Manual (NNSA/NSO, 2004f). This modification will not affect or modify any non-FFACO requirements for fencing, posting, or monitoring at this site. 
Nevada

Environmental

Restoration

Project

Recommendations and Justifications for Modifications for Use Restrictions Established under the U.S. Department of Energy, National Nuclear Security Administration Nevada Site Office

Federal Facility Agreement and Consent Order

Controlled Copy No.:

Revision No.: 0

February 2008

Approved for public release; further dissemination unlimited.

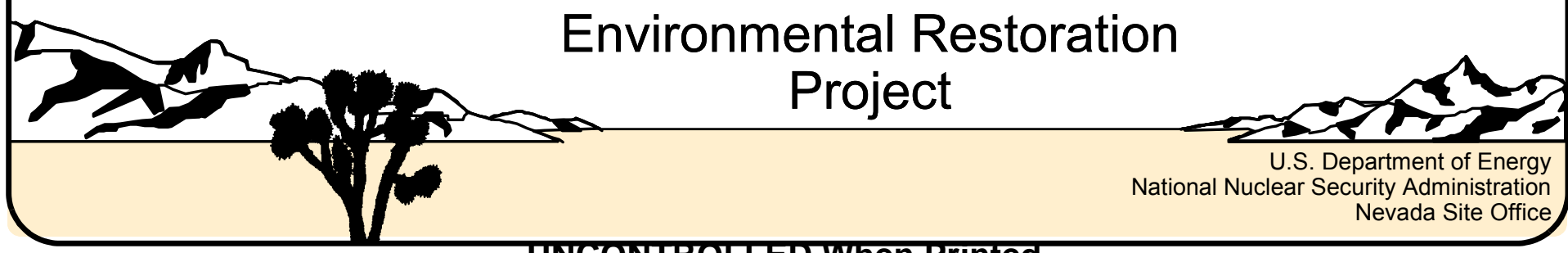


Recommendations and Justifications for Modifications for Use Restrictions Established under the U.S. Department of Energy, National Nuclear Security Administration Nevada Site Office Federal Facility Agreement and Consent Order

Approved by: /s/ Kevin J. Cabble

Date: $02 / 05 / 2008$

Kevin J. Cabble

Federal Sub-Project Director

Industrial Sites Sub-Project

Approved by:

/s/ John B. Jones

Date: $02 / 04 / 2008$

John B. Jones

Acting Federal Project Director

Environmental Restoration Project 
February 26, 2008

John B. Jones

Acting Federal Project Director

Environmental Restoration Project

National Nuclear Security Administration

Nevada Site Office

P. O. Box 98518

Las Vegas, NV 89193-8518

RE: Approval of Recommendations and Justifications for Modifications for Use Restrictions

Established under the U.S. Department of Energy, National Nuclear Security Administration, Nevada Site Office Federal Facility Agreement and Consent Order

Dear Mr. Jones:

The Nevada Division of Environmental Protection, Bureau of Federal Facilities (NDEP) staff has received and reviewed the February 2008 final report for Recommendations and Justifications for Modifications for Use Restrictions Established under the U.S. Department of Energy, National Nuclear Security Administration, Nevada Site Office. The NDEP approves the requested changes to the previously agreed upon use restrictions for those Corrective Action Sites (CASs) as described in the report.

Address any questions regarding this matter to either Ted Zaferatos at (702) 486-2850, ext. 234 , or me at (702) 486-2850, ext. 231.

Sincerely

\section{/s/ Tim Murphy}

\section{T.H. Murphy}

Chief

Bureau of Federal Facilities

$\mathrm{TZ}$

cc: $\quad$ E.F. DiSanza, WMP, NNSA/NSO

FFACO Group, PSG, NNSAINSO, Las Vegas, NV

David C. Loewer, DTRAVCXT1, M/S 645, Mercury, NV

W.R. Griffin, SNJV/DTRA, M/S 645, Mercury, NV

T.A. Thiele, NSTec, Las Vegas, NV

R.F. Boehlecke, SNJV, Las Vegas, NV

K. J. Cabble, ERP, NNSANSO, Las Vegas, NV

John Wong. Jeff MacDougall, Dennis Nicodemus, NDEP Las Vegas, NV 


\subsection{CAU 398, CAS 25-25-17 - Subsurface Hydraulic Oil Spill}

\subsection{CAS Description}

Corrective Action Site 25-25-17 consists of a hydraulic oil spill identified on December 1, 1998, during the housekeeping closure of CAS 25-25-01 at CAU 297. Because the spill was more extensive than originally believed, CAS 25-25-17 was created. The spill occurred as a result of the continual overfilling of two 10-gal aboveground metal containers, which were used for recirculating oil in a vacuum pump oil recovery system at E-MAD Building 3900 (NNSA/NV, 2001f).

The vacuum oil recovery system was installed in approximately 1965 and operated until the early to mid-1970s. Closure of the vacuum oil recovery system was completed on December 1, 1998. Disposal of the tanks, associated piping, and the first few inches of impacted soil was performed on January 14, 1999. This release was reported to the Nevada Division of Emergency Management on January 21, 1999, as case number NDEM \#99-0120-3281 (NNSA/NV, 2001f).

The spill is in a significant power/utility corridor feeding into Building 3900 . The quantity of oil released to the soil was estimated to be greater than 25 gal. While excavating, utilities were identified at a depth of approximately $3 \mathrm{ft}$. Impacted soil was removed to a depth of $18 \mathrm{in}$. Work was discontinued due to the extent of the impacted area, confining work space limitations, and proximity to utilities. Clean soil was used as backfill over the excavated area (NNSA/NV, 2001f).

\subsection{Current Use Restriction Description}

The future use of any land affected by this UR is restricted from any DOE or Air Force activity that may alter or modify the containment control, as approved by the state and identified in the CAU CR or other CAU documentation, unless appropriate concurrence is obtained in advance. The UR states: "Note, the spill site is within the Utility Corridor at E-MAD. Use restrictions apply to the area within the utility corridor." There are no annual monitoring or inspection requirements (NNSA/NSO, 2003e).

\subsection{Basis for Current Use Restriction}

Samples of the pre-excavation soils at the site were analyzed for TPH (diesel and oil), TCLP VOCs, TCLP SVOCs, TCLP metals, PCBs, pesticides, and gamma spectroscopy. Total petroleum hydrocarbons and PCBs were identified as COCs. Following removal of the 
contaminated soils, TPH (Oil) was the only COC present exceeding the PAL of $100 \mathrm{mg} / \mathrm{kg}$ at concentrations up to $600 \mathrm{mg} / \mathrm{kg}$. No VOCs or SVOCs were detected above PALs. Due to site conditions (e.g., location of utilities, limited space, depth to bedrock, and poor lighting) and limited access, the site was closed in place with a UR (NNSA/NSO, 2003e).

Table 22-1 contains analytical results of all COCs at CAS 25-25-17 that are the basis for the current UR. The sample matrix for all samples is soil.

Table 22-1

Sample Results for COCs at CAS 25-25-17 Used To Establish Current Use Restriction

\begin{tabular}{|c|c|c|}
\hline \multirow[b]{2}{*}{ Sample id } & \multirow{2}{*}{$\begin{array}{c}\text { Depth } \\
\text { (ft bgs) }\end{array}$} & TPH (Oil) \\
\hline & & $\begin{array}{c}\text { PAL } \\
100 \mathrm{mg} / \mathrm{kg}\end{array}$ \\
\hline $252517-1-1$ & 1 & 600 \\
\hline $252517-2-1$ & 1 & 530 \\
\hline
\end{tabular}

\subsection{Basis for Use Restriction Modification}

The revised FALs associated with the TPH contamination were established based on the PALs of hazardous constituents of TPH diesel as described in Section 2.2.2. Hazardous constituents of TPH diesel were not detected in any of the samples at concentrations greater than their respective PALs (NNSA/NSO, 2003e). Therefore, no contaminants are present at this site in concentrations exceeding the revised FALs, and all revised FALs were established at the PAL concentrations.

\subsection{Proposed Modification}

Remove the FFACO UR and associated fencing and postings from this CAS. 


\section{References}

FFACO, see Federal Facility Agreement and Consent Order.

Federal Facility Agreement and Consent Order. 1996 (as amended). Agreed to by the State of Nevada; U.S. Department of Energy, Environmental Management; U.S. Department of Defense; and U.S. Department of Energy, Legacy Management.

NNSA/NSO, see U.S. Department of Energy, National Nuclear Security Administration Nevada Site Office.

NNSA/NV, see U.S. Department of Energy, National Nuclear Security Administration Nevada Operations Office.

U.S. Department of Energy, National Nuclear Security Administration Nevada Operations Office. 2001f. Streamlined Approach for Environmental Restoration (SAFER) Plan for Corrective Action Unit 398: Area 25 Spill Sites, Nevada Test Site, Nevada, Rev. 0, DOE/NV--785. November. Las Vegas, NV.

U.S. Department of Energy, National Nuclear Security Administration Nevada Site Office. 2003e. Closure Report for Corrective Action Unit 398: Area 25 Spill Sites, Nevada Test Site, Nevada, Rev. 1, DOE/NV--873 REV 1. April. Las Vegas, NV.

U.S. Department of Energy, National Nuclear Security Administration Nevada Site Office. 2004f. NV/YMP Radiological Control Manual, DOE/NV--11718-079, Rev. 5. Prepared by Bechtel Nevada. Las Vegas, NV.

U.S. Department of Energy, National Nuclear Security Administration Nevada Site Office. 2006c. Industrial Sites Project Establishment of Final Action Levels, Rev. 0, DOE/NV--1107. Las Vegas, NV. 


\section{Library Distribution List}

\section{$\underline{\text { Copies }}$}

U.S. Department of Energy

National Nuclear Security Administration

Nevada Site Office

Technical Library

P.O. Box 98518, M/S 505

Las Vegas, NV 89193-8518

U.S. Department of Energy

Office of Scientific and Technical Information

P.O. Box 62

Oak Ridge, TN 37831-0062

Southern Nevada Public Reading Facility

c/o Nuclear Testing Archive

P.O. Box 98521, M/S 400

Las Vegas, NV 89193-8521

Manager, Northern Nevada FFACO

Public Reading Facility

c/o Nevada State Library \& Archives

100 N Stewart Street

Carson City, NV 89701-4285
1 (Uncontrolled, electronic copy)

1 (Uncontrolled, electronic copy)

2 (Uncontrolled, electronic copies)

1 (Uncontrolled, electronic copy) 